\title{
Phragmipedium warscewiczii, a new record for the Mexican orchid flora
}

\section{Phragmipedium warscewiczii, un registro nuevo para la orquideoflora mexicana}

\author{
Rodolfo Solano-Gómez ${ }^{1 *}$ and Eduardo Martínez-Ovando² \\ ${ }^{1}$ Centro Interdisciplinario de Investigación para el Desarrollo Integral Regional unidad Oaxaca, Instituto Politécnico Nacional. Hornos 1003, 71230, \\ Santa Cruz Xoxocotlán, Oaxaca, México. \\ ${ }^{2}$ Universidad de Ciencias y Artes del Estado de Chiapas, Libramiento Norte-Poniente s/n. Col. Lajas-Maciel, 29039, Tuxtla Gutiérrez,Chiapas, México. \\ *Correspondent: solanogo@yahoo.com.mx
}

\begin{abstract}
Phragmipedium warscewiczii is reported as new record for the Mexican orchid flora from material recently collected in Chiapas. The species is described from Mexican specimens and it is compared with P. exstaminodium, its closest ally. The Mexican locality is the northernmost and most distant population for $P$. warscewiczii. Information on nomenclature, distribution, habitat, and factors of risk for this orchid is provided.
\end{abstract}

Key words: Chiapas, cloud forest, Cypripedioideae, Phragmipedium section Caudatum, Phragmipedium exstaminodium, endangered species.

Resumen. Phragmipedium warscewiczii es reportada como registro nuevo para la orquideoflora mexicana a partir de material recientemente recolectado en Chiapas. Esta especie se describe a partir de ejemplares mexicanos y se le compara con P. exstaminodium, su pariente más cercano. La localidad mexicana es la más norteña y más distante para $P$. warscewiczii. También se proporciona información sobre nomenclatura, distribución, hábitat y factores de riesgo de esta orquídea.

Palabras clave: Chiapas, bosque nublado, Cypripedioideae, Phragmipedium sección Caudatum, Phragmipedium exstaminodium, especie amenazada.

\section{Introduction}

Phragmipedium is an orchid genus distributed throughout the tropics of America (except in the Caribbean islands), but with most of the species found in Ecuador and Peru. The group is recognized by the fan-like plants, absence of pseudobulbs, conduplicate leaves, lateral sepals fused into a synsepal, lip calceolate, column with 2 anthers, and a 3-loculate ovary. The genus has showy and spectacular flowers which are highly appreciated in horticulture. Unfortunately, this has motivated the extraction of wild specimens for cultivation and, together with the loss and transformation of their habitats, it has driven most species to the brink of extinction and currently all Phragimipedium species are included in Appendix I of CITES (Convention on International Trade in Endangered Species). No agreement has been reached about the number of species that should be recognized in Phragmipedium.

Recibido: 23 abril 2009; aceptado: 28 junio 2010
McCook (1998) recognized 15 species while Garay (1979) and Gruss (2003) accepted 21.

In Mexico, the genus was represented by one species, P. exstaminodium Castaño, Hágsater et E. Aguirre, which was described in 1984 from plants collected in Chiapas. This taxon was relatively common locally in the past, but their populations have decreased severely and it is now considered as one of the most endangered orchids in the country (Soto Arenas, 2003; Soto Arenas and Solano, 2007). Subsequently this species also has been reported from Guatemala (Atwood and Dressler, 1998; Dix and Dix, 2000; Dressler, 2005). Another Phragmipedium species present in Central America is $P$. warscewiczii (Rchb.f.) Christenson, commonly known as "Barbuda" in Guatemala and "Chinela" in Panama. In the past this orchid has been known by other names, such as $P$. caudatum (Lindl.) Rolfe (Ames and Correll, 1952; Hamer, 2001), P. humboldtii (Warsz. ex Rchb.f.) J.T.Atwood et Dressler (Dix and Dix, 2000; Populin, 2002; Correa et al., 2004), P. exstaminodium subsp. warscewiczii (Dressler, 2005) or P. warscewiczianum (Rchb.f.) Garay (Garay, 1979), but recently Christenson (2006) considered that the 
first name for this species was provided by Reichenbach (1873), Selenipedium warscewiczii, hence $P$. warscewiczii is the correct name for this orchid and it is accepted in the database of the International Plant Name Index (IPNI, 2010). Also, we follow Dressler (2005) considering that is best to use the oldest epithet for the species, warscewiczii, because it has been widely and persistently used for this orchid. In Guatemala P. warscewiczii grows in localities close to the Mexican border, so its presence in Chiapas was expected. This work documents the discovery of a population of this species in a cloud forest in southwestern Chiapas.

\section{Description}

Phragmipedium warscewiczii (Rchb.f.) Christenson, J. Orchideenfr. 13: 142. 2006.

Basionym: Selenipedium warscewiczii Rchb.f., Xenia Orchid. 2: 189. 1873. Type: Panamá. Chiriquí, Warscewicz 41 (W no. 15682).

Other synonyms: Cypripedium humboldtii Warsz, Bot. Zeitung (Berlin) 10: 691. 1852; nom. nud.

Cypripedium caudatum (Lindl.) Rolfe var. roseum hort. ex Delch., Rev. Hort. 39: 133. 1867 (as Cypripedium caudatum roseum).

Phragmipedium caudatum (Lindl.) Rolfe var. roseum Delch., Rev. Hort. 39: 133. 1867.

Phragmipedium caudatum (Lindl.) Rolfe var. warscewizianum (Rchb. f.) Gruss, Die Orchidee 44(3): 134. 1993.

Phragmipedium exstaminodium Castaño, Hágsater et E.Aguirre subsp. warscewiczii Dressler, Orchid Digest 69: 89. 2005.

Phragmipedium humboldtii (Warsz.) J.T.Atwood et Dressler, Selbyana 19(2): 246, f. 1. 1999 [“1998”], nom. illeg.

Phragmipedium popowii Braem, Ohlund et Quéné, Richardiana 4(4): 185-186, photogr. p. 191. 2004.

Phragmipedium warszewiczianum (Rchb.f.) Garay, Orchid Digest 43(4): 140. 1979 (sensu Garay, 1979, non Schltr., 1922).

Epiphytic, caespitose herb up to $36 \mathrm{~cm}$ in height including the inflorescence, each individual formed by 3-4 "fans" of leaves. Roots cylindrical in transection, elongate, branching toward the apex, up to $6 \mathrm{~mm}$ in diameter, covered with brown-reddish pubescence. Stems very reduced, united by inconspicuous rhizome segments. Leaves 5-6 per fan, distichous, basally imbricating, ligulate-oblong, obtuse, coriaceous, bright green, paler at the base, $23.7-32 \times 3-3.4 \mathrm{~cm}$; basal leaves longest, the upper ones progressively shorter. Inflorescence an apical raceme, $22-31 \mathrm{~cm}$ in height; peduncle velutinous, shorter than the leaves, pubescent, the hairs golden; peduncle bract leaf-like, conduplicate, greenish; rachis with 2 flowers that open more or less simultaneously. Floral bracts similar to that of the peduncle, imbricating, green tinged with red on the external surface, $4.3-4.7 \times 1.3-2.6 \mathrm{~cm}$. Ovary articulated with the pedicel, shedding when the flower become withered, pubescent, slightly arching, gradually thickened toward the apex, $11-13 \mathrm{~cm}$ long. Flowers very showy, slightly pendent; sepals cream-yellow, tinged with dark-green or purple along the veins; petals yellow, tinged with dark-green and/or purple along the veins, purple at the apex, pubescent on the external surface, the hairs purple; lip with the external surface white-cream, tinged with dark-green along the veins, with a large purple spot at the apex, edge of the apical orifice greenish-yellow with purple dots, lateral lobes dotted with purple, the internal surface white dotted with purple, covered at the edge by golden pubescence; column yellow-green at the base and purple toward the apex, covered by golden hairs; lobes of the staminodium purple, with a greenish white triangular spot between them. Dorsal sepal lanceolate, tailed, undulate along the margins, convex, the tail with revolute margins and deflexed at the apex, $11.3-14.3 \times 1.9-2.1 \mathrm{~cm}$. Lateral sepals totally fused into an elliptic-lanceolate, acuminate-tailed synsepal, undulate, channeled along the apical margins, $10.2-12.5 \times 3.5-5.2 \mathrm{~cm}$. Petals pendent, twisted, narrowly lanceolate, linear, tailed, pubescent on both surfaces, the hairs longest toward the apex, the basal margins undulate, ciliate, revolute, $12.6-29.6 \times 0.7-1.2 \mathrm{~cm}$, the tails $2-4 \mathrm{~mm}$ wide. Lip calceolate, triangular, rounded, with 2 orifices, one apical, triangular, and the other basal circular; lateral lobes conspicuous, induplicate in the apical orifice; edge of the basal orifice thickened; the external surface with long hairs along the edge of apical orifice, slightly sulcate along the veins toward the apex; 3.2-7.6 $\times 2.1-2.9 \mathrm{~cm}$. Column 1-1.4 $\times 0.4-0.6 \mathrm{~cm}$, with one fertile stamen at each side and a shield-like staminode, the latter with 2 symmetrical, triangular-oblong divergent lobes. Stigma fleshy, subclavate-obovoid, thickened toward the apex, rounded, pubescent. Pollinia 4 (Figs. 1-2). Capsules not observed.

\section{Taxonomic summary}

Specimens examined: Mexico. Chiapas, mountain slopes of the Sierra Madre de Chiapas toward the Central 


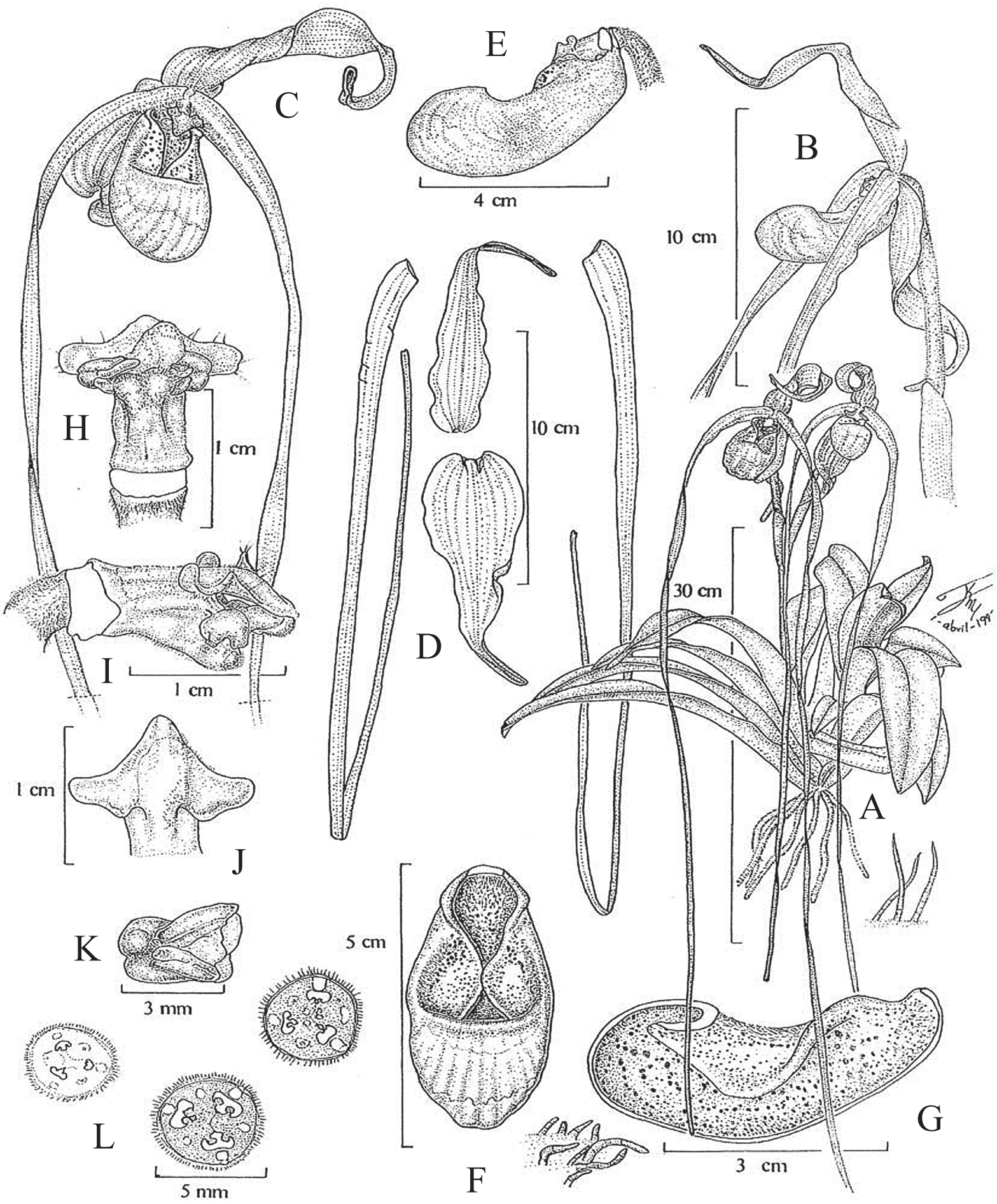

Figure 1. Phagmipedium warscewiczii. A, habit. B, flower from side. C, flower in oblique view. D, floral dissection with sepals and petals. E, lip from side. F, lip from front. G, longitudinal section of lip. H, Column from below. I, column from side. J, staminode. K, anther. L, cross sections of ovary. Drawn with camara lucida by R. Jiménez based on a specimen collected in Guatemala, G. A. Salazar 4454. 

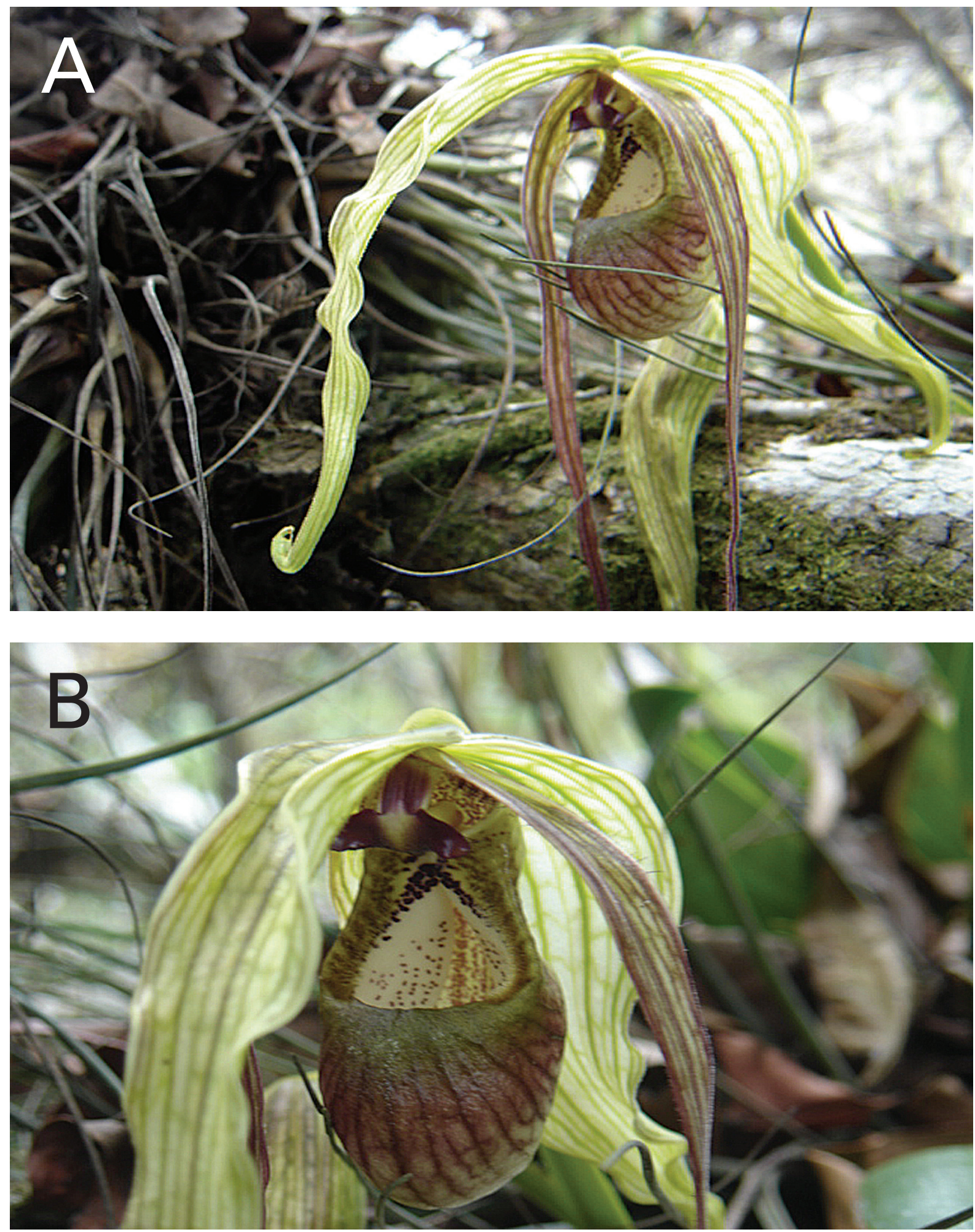

Figure 2. Phragmipedium warscewiczii. A. Flower in oblique view from a plant found on a fallen tree in its habitat. B. Flower from front showing the staminode and the apical orifice of the lip. Photographs by Eduardo Martínez Ovando based on E. Martinez Ovando 20. 
Depression, 1487 m elevation, epiphyte, May 1, 2008, E. Martínez Ovando 20 (AMO, OAX); same data, E. Martínez Ovando 21, 22, 23, 24 and 25 (HEM).

Distribution and habitat. This species has been reported from Mexico, Guatemala, Honduras, Costa Rica, Nicaragua, and Panama. In Mexico it is known from southwestern Chiapas, where it grows in the cloud forest on alluvial soils on karstic substrate (in order to protect the only Mexican population known of this sought-after species, the precise locality is not disclosed). The forest in the only known locality has 3 canopy strata. The upper canopy reaches a height of $25 \mathrm{~m}$ and is dominated by Coccoloba sp., Ficus sp., Fraxinus uhdei (Wenz.) Lingelsh., Prunus salasii Standl., and Ulmus mexicana (Liebm.) Planch. The intermediate stratum is more or less $20 \mathrm{~m}$ in height and is composed of Alnus sp., Ardisia sp., Eugenia capuli (Schtdl. et Cham.) Hook. et Arn., Ilex sp., and Parathesis sp. The inferior stratum does not exceed $15 \mathrm{~m}$ in height and is composed of species such as Cedrela tonduzii C.DC., Croton draco Schtdl. et Cham., Inga oerstediana Benth. ex Seem., and Zapoteca sp. There is an understory represented mainly by shrubby elements like Aphelandra schiedeana Schtdl. et Cham. and Psychotria sp. in the more open sites, while in the shadier parts Chamaedora benziei Hodel, C. carchensis Standl. et Steyerm., C. pinnatifronts H.Wendl., C. quezalteca Standl. et Steyerm., C. stolonifera H.Wendl. ex Hook.f., and Geonoma sp. are common. The epiphytic component is well represented and includes aroids, bromeliads, orchids, mosses, and some cacti. The climate reported for this region is $(A) C(w 1)$, i.e semi-warm/semi-wet (INEGI, 1980a; Garcia, 1988), mean temperate is higher than $18^{\circ} \mathrm{C}$, less than $18^{\circ} \mathrm{C}$ in the coldest month, and more than $22^{\circ} \mathrm{C}$ in the warmest month. Average annual rainfall is approximately $1500 \mathrm{~mm}$, most of the rain occurring between May and October, while the dry season is from November to April. Between 5\% and $10.2 \%$ of the total rainfall occurs in winter (INEGI, 1980a). Phragmipedium warscewiczii is an epiphyte on the inner branches of Coccoloba sp., where it grows on abundant accumulations of organic matter, mosses and lichens. The plants share the epiphytic habit with other orchids such as Acianthera circumplexa (Lindl.) Pridgeon et M.W.Chase, Arpophyllum giganteum Hartw. ex Lindl., Dinema polybulbon (Sw.) Lindl., Epidendrum alabastrialatum G.E.Pollard ex Hágsater, E. eustirum Ames, F.T.Hubb. et C.Schweinf., Lepanthes sp., Maxillaria cucullata Lindl., Restrepia muscifera (Lindl.) Rchb.f. ex Lindl., Specklinia fuegii (Rchb.f.) R.Solano et Soto Arenas, S. segregatifolia (Ames et C.Schweinf.) R.Solano et Soto Arenas, Stelis chiapasensis R.Solano, S. gracilis Ames, and S. leucopogon Rchb.f.

Phenology. The new shoots emerge in August and
September; they are fully developed by December or January. The inflorescence begins to develop by the end of February, and the flowers open from the beginning of May through June. A flower is fully developed in approximately 10 days and withers after 18 days. The maturation of the capsules takes approximately 7 months, from May to December, since in the field some dry capsules were observed shortly after seed dispersal in December. The plants undergo a dormant period from June to September Conservation status. Currently the habitat of this species is a small area of fragmented cloud forest, restricted to the internal slopes of the Sierra Madre of Chiapas and isolated from other similar forests. This habitat is surrounded by drier and disturbed deciduous and semi-deciduous tropical forests; there are also neighboring patches of moist pineoak forest (INEGI, 1980b). The more common productive activities in the region are coffee cultivation, subsistence agriculture in marginal soils, and wood extraction, all of which contribute to the loss of habitat for $P$. warscewiczii. The practice of wood extraction by local people frequently affects the phorophytes of this species, which forms colonies of several individuals; on one fallen tree up to 15 individuals of $P$. warscewiczii were counted. In the city of Tuxtla Gutiérrez orchid vendors ("materos") were recently observed offering plants of this species which probably were extracted from the locality reported here. The only Mexican population of $P$. warscewiczii is very localized and distant from the remaining localities of this species in Central America, which suggests the possibility that genetic differences have accumulated. Therefore, it is recommended to consider this orchid as endangered in México, as is its ally P. exstaminodium (Soto Arenas and Solano, 2007).

\section{Remarks}

Phragmipedium warscewiczii is a member of the Phragmipedium caudatum complex, belonging in Phragmipedium section Caudatum (Garay, 1979; Gruss, 1993, 2003; Atwood and Dressler, 1998; Braem and Ohlud, 2004; Braem et al., 2004). In the past it was common in the taxonomic and horticultural literature to refer to this orchid as a variety of $P$. caudatum (see Gruss, 1993, 2003) and, indeed, this species is closely related to P. caudatum and $P$. exstaminodium. Phragmipedium caudatum is distinguished by their smaller flowers, 3-lobed staminode, and distribution confined to Ecuador and Peru (Garay, 1979; Braem and Ohlund, 2004; Braem et al., 2004). On the other hand, P. exstaminodium has less robust plants and the flowers lack a well defined staminode, but in 
other aspects it is indistinguishable from $P$. warscewiczii. Nevertheless, Atwood and Dressler (1998), Soto Arenas (2003), Dressler (2005), and Christenson (2006) consider that $P$. exstaminodium represents autogamous, marginal populations of $P$. warscewiczii geographically restricted at the northernmost extreme of its distribution, and as such these authors treat the former as a subspecies of the second. The population reported here is the most outlaying and marginal one for $P$. warscewiczii, and it is separated by almost $180 \mathrm{~km}$ from the nearest known population of $P$. exstaminodium. The latter appears to have evolved into a different species within the distribution range of $P$. warscewiczil, possibly due to the emergence of a mutant without a staminode able to survive and spread. All populations of $P$. exstaminodium are consistent in the absence of a staminode, and all individuals are selfpollinating (Castaño et al., 1984; Soto Arenas and Solano, 2007). On the other hand, in $P$. warscewiczii the presence of the staminode (Figure 2) acts as barrier between the fertile anthers and the stigma, avoiding self-pollination and resulting in obligate cross-pollination.

With this addition, the orchid subfamily Cypripedioideae is now represented in Mexico by 6 species, the previously reported Cypripedium dickinsonianum Hágsater, $C$. irapeanum Lex., C. molle Lindl., Mexipedium xerophyticum (Soto Arenas, Salazar et Hágsater) V. A. Albert et M. W. Chase, P. exstaminodium, and P. warscewiczii.

\section{Acknowledgements}

Rolando Jiménez prepared the drawing of $P$. warscewiczii. Robert L. Dressler and Phillip J. Cribb made helpful comments about the correct name for this species. Gerardo Salazar made a critical review of the manuscript. Anne Damon reviewed the English translation. To José Luis Alvarado, for his help in the field and his interest in the conservation of the species habitat.

\section{Literature cited}

Ames, O. and D. S. Correll. 1952. Orchids of Guatemala. Fieldiana: Botany 26:23-25.

Atwood, J. T. and R. L. Dressler. 1998. Clarifications and new combinations in the Phragmipedium caudatum complex from Central America. Selbyana 19:245-248.

Braem, G. J. and S. Ohlund. 2004. Une chausse-trappe linguistique: Phragmipedium caudatum, P. warszewiczianum, P. humboldtii. Richardiana 4:163-170.

Braem, G. J., S. Ohlund. and R. J. Quené. 2004. Le vra
Phragmipedium warszewiczianum pourrrait-il se présenter, s'il vous plaît? Le complexe Phragmipedium caudatum, éclaircissements, et description d'une nouvelle espèce. Richardiana 4:171-196.

Castaño, G., E. Hágsater and E. Aguirre-León. 1984. Phragmipedium exstaminodium: Una nueva especie de Chiapas, México. Orquídea (México City) 9:191-202.

Correa, A., M. D., C. Galdames and M. S. de Stapf. 2004. Catálogo de las Plantas Vasculares de Panamá. Smithsonian Tropical Research Institute, Panamá. 599 p.

Chrsitenson, E. A. 2006. Das frühere Phragmipedium caudatum aus Panama. Journal für den Orchideenfreund 13:141-143.

INEGI. 1980a. Carta de Precipitación Total Anual: Villahermosa, escala 1:1.000 000. Secretaría de Programación y Presupuesto. México, D.F.

INEGI. 1980b. Carta de Uso de Suelo y Vegetación: Tuxtla Gutiérrez (E15-11), escala 1:250 000. Secretaría de Programación y Presupuesto. México, D.F.

IPNI. 2010. The International Plant Names Index. Royal Botanic Gardens, Kew, Harvard University Herbaria, and Australian National Herbarium. Published on http://www.ipni.org.

Dix, M. A. and M. W. Dix. 2000. Orchids of Guatemala. A revised annotated checklist. Monographs in Systematic Botany from Missouri Botanical Garden 78:1-61.

Dressler, R. L. 2005. La Chinela, alive and well in Western Panama: notes on the Panamanian long-tailed Phragmipedium. Orchid Digest 69:86-91.

Garay, L. A. 1979. The genus Phragmipedium. Orchid Digest 43:133-148.

García, E. 1964. Modificaciones al sistema de clasificación climática de Köppen (para adaptarlo a las condiciones de la República Mexicana). (4th edition, 1987). Universidad Nacional Autónoma de México, México. 217 p.

Gruss, O. 1993. Die gattung Phragmipedium Rolfe (Teil 1). Sektion Phragmipedium Garay. Die Orchidee 44:129-136.

Gruss, O. 2003. A checklist of the genus Phragmipedium. Orchid Digest 67:213-241.

Hamer, F. 2001. Orchidaceae. In Flora de Nicaragua. Angiospermas (Fabaceae-Oxalidaceae), W. D.Stevens, C. Ulloa, A. Pool and O. M. Montiel (eds.). Monographs in Systematic Botany from Missouri Botanical Garden 85:1612-1860.

McCook, L.1998. An annotated checklist of the genus Phragmipedium. Orchid Digest 62 (Special publication):1-12.

Pupulin, F. 2002. Catálogo revisado y anotado de las orquídeas de Costa Rica. Lankesteriana 4:1-88.

Reichenbach, H. G. 1873. Xenia Orchidacea: Beiträge zur Kenntniss der Orchideen 2:189.

Soto Arenas, M. A. 2003. Phragmipedium humboldtii subsp. exstaminodium. pl. 635. In Icones Orchidacearum Fascicles 5-6: Orchids of México parts 2-3, E. Hágsater and M. Soto Arenas (eds.). Herbario AMO, México. 
Soto Arenas, M. A. and R. Solano. 2007. Ficha técnica de Phragmipedium exstaminodium. In Información actualizada sobre las especies de orquídeas del PROY-NOM-059-
ECOL-2001, M. A. Soto Arenas (comp). Instituto Chinoín A.C., Herbario AMO. Bases de datos SNIB-CONABIO. Proyecto W029, México, D.F. 
